\title{
Effect of Orlistat on serum Uric acid level in adults: A systematic review and meta-analysis of randomized controlled trials
}

\author{
Soheila Noori ${ }^{1}$, Atieh Mirzababaei ${ }^{1}$, and Khadijeh Mirzaei $^{1}$ \\ ${ }^{1}$ Tehran University of Medical Sciences School of Nutritional Sciences and Dietetics
}

September 17, 2020

\begin{abstract}
Objective: Hyperuricemia increases the risk of gout and cardiovascular diseases. Obesity increase the risk of hyperuricemia while weight loss $(>5 \mathrm{~kg}$ ) has been reported to decrease urate. The effects of orlistat on serum uric acid is still controversial. The aim of this meta-analysis was to evaluate the influence of orlistat on serum uric acid level in adults. Methods: Relevant studies, published up to May 2020, were searched systematically through PubMed/Medline, Scopus, and Google Scholar. All relevant randomized controlled clinical trials were included. Meta-analysis was performed using random-effect model. Subgroup analysis, sensitivity analysis, and meta-regression were also carried out Results: Overall 7 trials (9 dataset) that enrolled 1786 subjects were included. Orlistat showed in significant change in serum uric acid level (Difference in means: $-17.661 \mu \mathrm{mol}, 95 \%$ CI: -31.615 to $-3.707, \mathrm{P}=0.01)$. A low heterogeneity observed across the studies $\left(\mathrm{I}^{\wedge} 2=25.119 \%\right)$. After categorizing studies on the basis of duration and sample size the effect of orlistat on serum uric acid was significant. The results of meta-regression were showed that significant relationships were not found between orlistat and serum uric acid in duration of intervention. Conclusion: We found a significant reduction in serum uric acid following orlistat therapy in adults.
\end{abstract}

\section{Introduction}

Uric acid is the end product of purine metabolism and is secreted by the kidney[1]. Elevated levels of serum uric acid level (SUA) can result from decreased renal clearance[1]. Hyperuricemia is an abnormal condition with higher level of uric acid in the blood [2]. Hyperuricemia is due to an imbalance of increased production of uric acid or/and decreased excretion of uric acid, which may result in serious complications including gout, tophi, kidney stones, or urate nephropathy even kidney failure[1, 2] . In human, if the concentration of SUA reaches to $357 \mu \mathrm{mol} / \mathrm{l}(6 \mathrm{mg} / \mathrm{dl})$ for women and $416 \mu \mathrm{mol} / \mathrm{l}(7.0 \mathrm{mg} / \mathrm{dl})$ for men, hyperuricemia could be diagnosed [2]. Hyperuricemia increases the risk of gout, but it is also a risk factor for cardiovascular diseases (CVD)[3]. Uric acid seems to be involved in the pathogenesis of both coronary and carotid atherosclerosis [4]. Pro inflammatory properties of uric acid, accounting for this atherogenic potential, include a positive correlation of its concentration with increased levels of inflammatory markers, such as high-sensitivity Creactive protein (hs-CRP), interleukin-6, tumor necrosis factor $\alpha$ (TNF $\alpha)$ as well as of chemoattractant and adhesion molecules[4]. High levels of SUA will lead to sequelae including hypertension hypertriglyceridemia, and hypercholesterolemia[1]. Also, hyperuricemia has been associated with an increased risk for early death in patients with an acute stroke[1]. Hyperuricemia spans CVD and CKD; increased SUA level can enhance the risk for both these morbidities [2]. As a cardiovascular risk factor, SUA often accompanies metabolic syndrome, hypertension, diabetes, dyslipidemia and obesity [2].

Obesity and dyslipidemia increase the risk of hyperuricemia [2]. Adults with increasing Body Mass Index (BMI) over time show increased SUA and hs-CRP. Serum uric acid has also been shown to correlate with liver dysfunction and increased inflammatory markers[1]. In developed countries, hyperuricemia was proved to be related to obesity-induced metabolic dysfunction and body weight control can improved lifestyle, dyslipidemia and hyperuricemia and ameliorate metabolic risk factors Obesity in women and hypertriglyceridemia in 
men may aggravate hyperuricemia to develop gout [2]. Also have found a significant correlation between nonalcoholic fatty liver disease (NAFLD) and hyperuricemia. The higher SUA level accompanied the risk of NAFLD [5]. In developing countries, for example, an Indian study reported that the prevalence of hyperuricemia increased significantly in population with obesity [2].

Orlistat (tetrahydrolipstatin) which is $\beta$-lactone is the only Food and Drug Administration (FDA) approved PL inhibitor. Orlistat is marketed as weight loss drug at a therapeutic oral dose of $120 \mathrm{mg}$, three times a day[6]. Orlistat has been used for decades with no serious side-effects. It reversibly inhibits dietary lipid digestion in the gastrointestinal (GI) lumen, which leads to a modest weight loss [7]. Orlistat treatment in the conventional oral dosage forms is associated with frequent ( $20 \%$ of patients) GI side-effects, such as liquid and oily stools [7]. Weight loss $(>5 \mathrm{~kg}$ ) achieved by therapeutic lifestyle changes or bariatric surgery has been reported to decrease urate levels by 8.0 to $10.0 \mu \mathrm{mol} / \mathrm{dl}[8]$.

A study showed that, there is no changes in plasma uric acid among children with obesity in one trial[9]. Also a short study showed that statistically significant drop of plasma uric acid levels [10]. The last meta-analysis is the first study to consider the effect of antiobesity drugs (orlistat) on serum uric acid focused its attention on patients with obesity and other metabolic disease only and not on a specific drugs. On the contrary, we aimed to carry out a meta-analysis of randomized controlled trials to specifically investigate if orlistat therapy is associated to decreased uric acid in adults and to assess the magnitude of the decrease in serum uric acid levels. Our study incorporate a sufficient number of RCTs but include articles only in English language.

\section{Methods}

\section{Search strategy}

This meta-analysis was undertaken according to the Preferred Reporting Items of Systematic Reviews and Meta-Analysis (PRISMA) statement guideline [11] and Cochrane handbook for systematic reviews of interventions[12]. Two independent authors systematically searched literature in online medical search engines including PubMed/Medline, Scopus and Google Scholar were searched for relevant articles published from inception until May 2020. Combination of both following MESH and non-MESH terms were used: (orlistat[MeSH Terms] OR Tetrahydrolipstatin[MeSH Terms] OR THLP[MeSH Terms] OR Tetrahydrolipastatin[MeSH Terms] OR Alli[MeSH Terms] OR Xenical[MeSH Terms] OR Roche brand of orlistat[Title/Abstract]) OR Hoffmann-La Roche brand of orlistat[Title/Abstract]) AND (Uric acid[MeSH Terms] OR Acid, Uric[MeSH Terms] OR 2,6,8-Trihydroxypurine[MeSH Terms] OR Trioxopurine[MeSH Terms] OR Urate[MeSH Terms] OR Blood uric acid[Title/Abstract] OR Hyperuricemia[Title/Abstract] OR HU[Title/Abstract] OR Serum uric acid[Title/Abstract] OR SUA[Title/Abstract] OR High serum uric acid [Title/Abstract] OR HSUA level[Title/Abstract] OR UA[Title/Abstract]). The search was also completed by manual search of the references list of clinical trials and previous review articles to include other potentially eligible trials. Language restrictions (English) were applied in our search strategy. The PubMed's e-mail alert service was also activated to find any new articles that might appear in this area after our primary search.

\section{Inclusion criteria}

Potentially relevant studies were included if they met the following inclusion criteria: (1) original papers with either parallel or cross-over randomized clinical trials (RCT) design; (2) studies conducting on individuals aged 18 years old or more; (3) investigating the impact of orlistat on uric acid (4) providing required information on outcomes at both baseline and the end of trial (or reported changes in outcomes) for each group (orlistat/control),(5) publications examining the effects of orlistat in combination with other interventions and (6) full-text publication was written in English;.. After removal of duplicates, two reviewers independently screened studies by title, abstract, and full text as applicable for inclusion.

\section{Exclusion criteria}

Publications were excluded if they were: (1) molecular and animal studies, literature reviews, conference pa- 
per, observational studies, case reports, republished data, book, letters, (2) Non interventional, un-controlled and nonrandomized trials, (3) without adequate outcome for both baseline and the end of trial. (4) In addition, unpublished data and gray literature such as patents, congress abstracts, and dissertations were excluded.

\section{Data extraction}

The following items were subtracted from the eligible publications by using the standard spreadsheets presented in published RCTs: study characteristics (first author, publishing year and study design), participant characteristics (sample size, age, note about subject, gender, health status) and intervention (type of intervention (study group), duration and dosage). The outcome measures included mean and standard deviation (SD) and changes in serum uric acid at baseline, and the end of the study. If additional details were needed, we contacted study authors. Values reported on $\mathrm{mg} / \mathrm{dl}$ for serum uric acid were converted to $\mu \mathrm{mol} / \mathrm{l}$ by multiplying to 59.48 .

\section{Quality assessment of studies}

S-N and A-M used the criteria provided by the Cochrane Collaborations tool for assessment of quality and risk of bias in selected studies[13]. Methodological features applied for assessment were: (a) random sequence generation; (b) allocation concealment; (c) blinding of participants and personnel; (d) blinding of outcome assessment; (e) incomplete outcome data, (f) selective outcome reporting (reporting bias), and (g) other potential sources of bias. According to the recommendations of the Cochrane Handbook, studies were assessed to have a high risk, low risk or unclear. Poorly reported articles were labeled an item as "unclear", suggesting an unclear or unknown risk of bias.

\section{Statistical analysis}

We estimated the effect of orlistat on serum uric acid level by pooling baseline and final mean differences and standard deviation (SD) values and $95 \%$ CI of the studies in both intervention and control groups. A random-effects model by DerSimonian and Laird method [14] was used to estimate the overall effect size. In addition, standard error of mean (SEM) was converted to SD by following the formula[15]: SD = SEM $\times$ $\sqrt{n}(\mathrm{n}=$ number of participants in each group). SDs of the mean differences were calculated as follows:

$\mathrm{SD}_{\text {Change }}=\sqrt{\left(\left(S D_{\text {Baseline }}\right)^{2}+\left(S D_{\text {Final }}\right)^{2}\right)-\left(2 \times R \times \mathrm{SD}_{\text {Baseline }} \times \mathrm{SD}_{\text {Final }}\right)}$ assuming a correlation coefficient (R) 0.5 as it is a conservative estimate for an expected range of 0-1. Between studies heterogeneity was examined using Cochrane's Q test (significance point at $\mathrm{P}<0.1$ ) and $I^{2}$ statistic with values greater than $50 \%$ as evidence of moderate to high heterogeneity.[16]. In order to find the potential sources of heterogeneity, we performed subgroup analyses to evaluate whether results were different by intervention period (3 month and 6 month, sample size ( $<100$ and [?] 100 participants), health status (metabolic syndrome, hypercholesterolemia, PCOS and NAFLD). We also performed sensitivity analysis by removed each study from the analysis. Then, potential publication bias was assessed by using Egger's test [17] and Begg's regression test. In case of detecting potential publication bias $\mathrm{P}$ values less than 0.05 . Duval \& Tweedie "trim and fill" approach was applied to adjust analysis for the impacts of publication bias[18]. Random-effects meta-regression analysis was conducted to evaluate the association between changes in serum uric acid and potential confounders including duration of treatment. The collected information from studies was imported into Comprehensive Meta-Analysis software version 2 (Biostat, Inc., Englewood, NJ, USA)[19]. A P value of $<0.05$ was considered as statistically significant.

\section{Results}

\section{Study selection}

A total of 1579 records were initially retrieved, of them 107 duplicate publications were removed. The flow diagram of detailed steps of the literature search process is illustrated in Fig1. After screening, we included 43 articles for further examination of full texts. Of these articles, 36 studies were excluded because of the following reasons: due to lack of sufficient data $(\mathrm{n}=3)$, duplicate of already included trial $(\mathrm{n}=2)$, review 
$\operatorname{study}(n=4)$, outcome of interest was not reported $(n=19)$, not a trial of active agent of interest $(n=5)$, nonrandomized or uncontrolled $(n=2)$, animal study $(n=1)$. Seven eligible trials were included in the final quantitative analysis [20-26].

\section{Study characteristics}

The general characteristics of the 7 qualified articles (9 dataset) are illustrated in Table 1. Selected eligible trials enrolled 1786 participants with age ranging from 18 to 65 years old and were conducted on both genders, except for one trial that exclusively included women [25]. A number of subjects in intervention and control groups were 896 and 890, respectively. Participants were patients with overweight and obesity[20, 22-26], untreated type 2 diabetes and untreated hypertension[20], type 2 DM treated with oral antidiabetic agents (metformin alone or in combination with sulfonylureas)[21, 22], metabolic syndrome[21-23], hypertension treated with drug[22, 24], coronary heart disease concomitant cardiac dysfunction [22], hypercholesterolemia [20, 24], PCOS [25], NAFLD [26]. All selected studies used a parallel design including a control group. Duration of orlistat therapy varied from 3 to 6 months. Daily prescribed dosage of orlistat varied between $120 \mathrm{mg}$ three times a day (tid) $[20,22-26]$ and $360 \mathrm{mg} / \mathrm{dl}$ [21]. Items that participants received with orlistat during the study include: low calorie $\operatorname{diet}[20,21]$, fat restricted diet and physical activity[22], low calorie/low fat diet and other medication[23-25] and in one study they didn't take anything with orlistat[26]. The quality assessment results of the articles are shown in Fig 2.

\section{Effect of orlistat on serum uric acid levels}

7 qualified studies (9 dataset) including a total of 1786 subjects, reported serum uric acid as their outcome. Combining their findings based on random-effects model, we found that serum uric acid was significantly

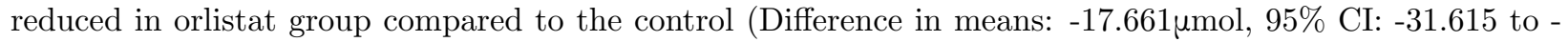
$3.707, \mathrm{P}=0.01)$ (Fig3), including no significant heterogeneity between studies $\left(I^{2}=25.119 \%\right.$, Q-value $\left.=10.68\right)$ .We removed one study and repeated the analysis after excluding the study while the findings did not change. Based on subgroup analysis includes intervention period (3month and 6 month), sample size $(<100$ and [?] 100 participants), health status (metabolic syndrome, hypercholesterolemia, PCOS and NAFLD) were responsible, at least to some extent, for between-study heterogeneity.

\section{Publication bias}

In the analysis of serum uric acid, funnel plot (Fig 6), Begg's Tests $(\mathrm{P}=0.60)$ and Egger's Tests $(\mathrm{P}=0.85)$ did not show any significant publication bias. Applying the "trim and fill" method, the findings for serum uric acid clearly showed that there are 2 missing studies imputed.

\section{Subgroup analysis}

Findings from the subgroup analyses are outlined in Table 2. After categorizing studies on the basis of duration of intervention revealed that the effect of orlistat on serum uric acid was significantly greater in trials lasted 6 months (Difference in means: $-20.178 \mu \mathrm{mol} / \mathrm{l}, 95 \%$ CI:-39.646 to 0.710, $\mathrm{P}=0.04$ ) than 3 months (Difference in means: $-12.977 \mu \mathrm{mol} / 195 \% \mathrm{CI}$ : -33.400 to $7.445, \mathrm{P}=0.21$ ). The subgroup analyses based on health status revealed that decreased serum uric acid was remarkable in patients with metabolic syndrome (Difference in means: $-33.885 \mu \mathrm{mol} / \mathrm{l}, 95 \% \mathrm{CI}$ : -75.402 to $7.633 ; \mathrm{P}=0.11$ ) and after that decreased serum uric acid was significantly remarkable in patients with hypercholesterolemia (Difference in means: $-19.300 \mu \mathrm{mol} / \mathrm{l}$ 95\% CI: $(-19.502$ to $-19.098, \mathrm{P}=0.00)$ than other PCOS groups (Difference in means: $-14.402 \mu \mathrm{mol} / \mathrm{l}$ 95\% CI: (-40.991 to 12.187, $\mathrm{P}=0.28)$. Also was observed serum uric acid increase in NAFLD patients (Difference in means: $7.461 \mu \mathrm{mol} / 1$ 95\% CI: -7.470 to $22.392, \mathrm{P}=0.32$ ). Moreover, reduction in serum uric acid after orlistat therapy in studies with sample size $>100$ was significantly greater (Difference in means: $-18.310 \mu \mathrm{mol} / 1$ 95\% CI: -36.045 to $-0.575, \mathrm{P}=0.043$ ) than studies with sample size $<100$ (Difference in means: $-17.105 \mu \mathrm{mol} / \mathrm{l}$ $95 \%$ CI: -36.745 to $2.535, \mathrm{P}=0.08$ ). Stratified on the basis of items were taken with orlistat, a significant reduction was observed in trials performed on patients were taken orlistat with low calorie diet (Difference in means: $-35.949 \mu \mathrm{mol} / 1$ 95\% CI: -66.772 to $-5.127, \mathrm{P}=0.02)$ in comparison with other groups.

\section{Sensitivity analysis}


Sensitivity analysis was conducted using leave one-out method, that is, iteratively removing one study each time and repeating the analysis. The overall estimate of effect size was not significantly driven by a single study (Fig 4).

\section{Meta - regression Analyses}

Random-effects meta-regression analysis (Fig 5) was done using the association of changes in serum uric acid with duration of study. The results showed that Significant relationships were not found between orlistat and serum uric acid in duration (slope: -3.01; SE: 5.88; $\mathrm{P}=0.60$ ) of intervention.

\section{Discussion}

The effect of orlistat on serum uric acid level has been examined in several studies and the results were inconsistent. To our knowledge, the present study is the first meta-analysis on the effect of orlistat on serum uric acid level. By analyzing the data from 7 clinical trials (9 dataset) involving 1786 participants, we found that orlistat could significantly decrease serum uric acid level in comparison with placebo/control.

Our finding of the effect of orlistat on serum uric acid level improvement was supported by evidence from previous trials [20,21] and in the first group of one trial [25]. However, in contrast to our results, some trials revealed that orlistat is caused decrease serum uric acid but not significantly $[22,24]$ and in the first group of one trial [26]. Also one trial [23] and in the second group of two trials [25, 26] were showed that increase serum uric acid after orlistat therapy.

When stratifying by health status, this meta-analysis shows a consistent protective effect of orlistat on serum uric acid in patients with hypercholesterolemia than other disease like metabolic syndrome, PCOS and NAFLD. Although we did not find any significant change of serum uric acid after orlistat therapy studies with sample size $<100$ but beneficial effect of orlistat on serum uric acid was observed in studies with sample size $>100$. When we classified based on the duration of the studies, a significant positive effect on serum uric acid levels was observed during 6 month. It is notable that in a group of participants who received a low-calorie diet with orlistat, the significant reduction was found in serum uric acid in comparison to other mentioned subgroups. Also, meta-regression suggested that significant relationships were not found between orlistat and serum uric acid in duration of intervention.

The potential mechanism of uric acid-lowering effect of orlistat is still unclear and further studies are warranted. The link between gout, obesity and metabolic syndrome is well-established. Post-bariatric surgery weight loss results in a significant and sustained improvement in SUA levels up to the third postoperative year, as well as a reduction in the incidence of gout attacks[27]. Weight loss $(>5 \mathrm{~kg})$ achieved by therapeutic lifestyle changes or bariatric surgery has been reported to decrease urate levels by 8.0 to $10.0 \mu \mathrm{mol} / \mathrm{dl}$ [8].Therefore, one of the possible mechanisms of orlistat for reducing uric acid is its weight loss effect. One meta-analysis also showed that SUA levels are significantly associated with dyslipidemia, and this association is impacted by age and gender [28]. The other meta-analysis demonstrated obesity is associated with multiple CVD risk factors such as dyslipidemia. The mechanism by which weight loss medications impact CVD risk reduction could be a direct effect of these agents or merely an effect of weight reduction itself. In addition, the mechanism of action of the medications are not directly anti-inflammatory, and do not directly modify insulin sensitivity, blood pressure or the lipid profile. Weight loss has been noted to modify risk factors via modifying the lipid profile. Thus, it is most likely that the benefit on cardiovascular disease from these therapies is via weight reduction and not direct medication effect. Pharmacological weight loss therapy may be a valuable treatment option to reduce CVD risk in patients with obesity [29]. Further research is needed to clarify the effects these therapies on overall mortality and evaluate the mechanisms by which these medications reduce CVD risk factors and mortality [29]. The findings of the prospective cohort study suggest that higher level of high-sensitivity CRP is an independent risk factor for hyperuricemia in Chinese, especially in women[30].While in one study significant associations between baseline SUA levels, and high-sensitivity C-reactive protein were identified but a decrease in SUA level from baseline to 24-week follow-up was not associated with significant changes in high-sensitivity C-reactive protein [31]. One metaanalysis study was demonstrated orlistat is effective in increasing plasma concentrations of adiponectin and 
decreasing those of leptin and CRP [32]. So it's not clear if orlistat can reduce serum uric acid by lowering CRP.

\section{Strengths and limitations}

Our study was the first meta-analysis of the effect orlistat on serum uric acid level and incorporated a sufficient number of RCT and publication in our analysis. We had precise search strategy. We didn't find substantial heterogeneity in our analysis. However, some limitations of the present study should be noted. First, the characteristics of included study participants were heterogeneous (i.e., patients with hypercholesterolemia, T2 DM, metabolic syndrome, PCOS, and NAFLD). In addition, the number of inclusion trials in some subgroups was few, which might results in false negative results. Moreover, we included articles only in English language and articles in other languages may influence our results. What also is important to be noted is that the included studies in our meta-analysis did not report their results for men and women separately. Accordingly, we were not able to compare the pooled effect size between men and women.

\section{Conclusion}

In conclusion, our meta-analysis shown reliable evidence that orlistat had a positive effect on uric acid level. Moreover, we found significant reduction of serum uric acid level after orlistat therapy in comparison with placebo/control. Further high-quality clinical trials will be required to provide sufficient evidence.

\section{Declarations}

\section{Funding}

Department of Community Nutrition, School of Nutritional Sciences and Dietetics, Tehran University of Medical Sciences (TUMS).

\section{Competing interests}

There is no Competing interests

\section{Availability of data and materials}

Not applicable

\section{Code availability}

Not applicable

\section{Authors' contributions}

Soheila Noori, Atieh Mirzababaei, Khadijeh Mirzaei

\section{Acknowledgments}

S-N and K-M designed the study. S-N and A-M did the literature search and screening data. S-N and A-M performed data extraction and quality assessment, independently. S-N analyzed and A-M interpreted data and wrote the manuscript. K-M supervised the study. All authors read and approved the final manuscript.

\section{References}

1. Foster, C., L. Smith, and R. Alemzadeh, Excess serum uric acid is associated with metabolic syndrome in obese adolescent patients.

2. Liu, F., et al., Hyperuricemia and its association with adiposity and dyslipidemia in Northwest China: results from cardiovascular risk survey in Xinjiang (CRS 2008-2012). Lipids Health Dis, 2020. 19 (1): p. 58.

3. Derosa, G., P. Maffioli, and A. Sahebkar, Plasma uric acid concentrations are reduced by fenofibrate: A systematic review and meta-analysis of randomized placebo-controlled trials. Pharmacol Res, 2015. 102 : p. 63-70. 
4. Katsiki, N., et al., Hyperuricaemia and non-alcoholic fatty liver disease (NAFLD): a relationship with implications for vascular risk? Curr Vasc Pharmacol, 2011. 9 (6): p. 698-705.

5. Catanzaro, R., et al., Non-alcoholic fatty liver disease: correlation with hyperuricemia in a European Mediterranean population. Acta Clin Belg, 2020: p. 1-6.

6. Khedr, N.F., A.M. Ebeid, and R.M. Khalil, New insights into weight management by orlistat in comparison with cinnamon as a natural lipase inhibitor. Endocrine, 2020. 67 (1): p. 109-116.

7. Holmback, U., et al., Effects of a novel combination of orlistat and acarbose on tolerability, appetite, and glucose metabolism in persons with obesity. Obes Sci Pract, 2020. 6 (3): p. 313-323.

8. Chales, G., How should we manage asymptomatic hyperuricemia? Joint Bone Spine, 2019. 86 (4): p. 437-443.

9. Norgren, S., et al., Orlistat treatment in obese prepubertal children: a pilot study. Acta Paediatrica, 2003. 92 (6): p. 666-670.

10. Diamanti-Kandarakis, E., et al., Short-term effect of orlistat on dietary glycotoxins in healthy women and women with polycystic ovary syndrome. Metabolism, 2006. 55 (4): p. 494-500.

11. Moher, D., et al., Preferred reporting items for systematic review and meta-analysis protocols (PRISMAP) 2015 statement. Syst Rev, 2015.4 : p. 1.

12. Higgins, J.P., et al., Cochrane handbook for systematic reviews of interventions. 2019: John Wiley \& Sons.

13. Higgins, J.P., et al., The Cochrane Collaboration's tool for assessing risk of bias in randomised trials. Bmj, 2011. 343 : p. d5928.

14. DerSimonian, R. and R. Kacker, Random-effects model for meta-analysis of clinical trials: an update. Contemp Clin Trial 28 (2): 105-114. 2007.

15. Hozo, S.P., B. Djulbegovic, and I. Hozo, Estimating the mean and variance from the median, range, and the size of a sample. BMC medical research methodology, 2005. 5 (1): p. 13.

16. Higgins, J.P. and S.G. Thompson, Quantifying heterogeneity in a meta-analysis. Stat Med, 2002. 21 (11): p. 1539-58.

17. Egger, M., et al., Bias in meta-analysis detected by a simple, graphical test. Bmj, 1997. 315 (7109): p. 629-634.

18. Duval, S. and R. Tweedie, Trim and fill: A simple funnel-plot-based method of testing and adjusting for publication bias in meta-analysis. Biometrics, 2000. 56 (2): p. 455-63.

19. Borenstein, M., et al., Comprehensive meta-analysis version 2. Biostat. Englewood NJ, 2005.

20. Guy-Grand, B., et al., Effects of orlistat on obesity-related diseases-a six-month randomized trial. Diabetes, Obesity and Metabolism, 2004. 6 (5): p. 375-383.

21. Didangelos, T.P., et al., The ORLIstat and CArdiovascular risk profile in patients with metabolic syndrome and type 2 DIAbetes (ORLICARDIA) Study. Curr Med Res Opin, 2004. 20 (9): p. 1393-401.

22. Cocco, G., S. Pandolfi, and V. Rousson, Sufficient weight reduction decreases cardiovascular complications in diabetic patients with the metabolic syndrome. Heart Drug, 2005. 5 (2): p. 68-74.

23. Filippatos, T.D., et al., Effect of orlistat, micronised fenofibrate and their combination on metabolic parameters in overweight and obese patients with the metabolic syndrome: the FenOrli study. Curr Med Res Opin, 2005. 21 (12): p. 1997-2006. 
24. Nakou, E.S., et al., The effect of orlistat and ezetimibe, alone or in combination, on serum LDL and small dense LDL cholesterol levels in overweight and obese patients with hypercholesterolaemia. Curr Med Res Opin, 2008. 24 (7): p. 1919-29.

25. Song, J., et al., Effect of orlistat or metformin in overweight and obese polycystic ovary syndrome patients with insulin resistance. Gynecol Endocrinol, 2018. 34 (5): p. 413-417.

26. Ye, J., et al., Effect of orlistat on liver fat content in patients with nonalcoholic fatty liver disease with obesity: assessment using magnetic resonance imaging-derived proton density fat fraction. Therap Adv Gastroenterol, 2019. 12 : p. 1756284819879047.

27. Yeo, C., et al., Impact of bariatric surgery on serum uric acid levels and the incidence of gout-A meta-analysis. Obesity Reviews, 2019. 20 (12): p. 1759-1770.

28. Chen, S., et al., Association between serum uric acid levels and dyslipidemia in Chinese adults: A cross-sectional study and further meta-analysis. Medicine (Baltimore), 2020. 99 (11): p. e19088.

29. Kane, J.A., et al., Cardiovascular Risk Reduction Associated with Pharmacological Weight Loss: A Meta-Analysis. Int J Clin Res Trials, 2019. 4 (1).

30. Dai, H.X., et al., Higher Levels of High-Sensitivity C-Reactive Protein Is Positively Associated with the Incidence of Hyperuricemia in Chinese Population: A Report from the China Health and Retirement Longitudinal Study. Mediators Inflamm, 2020. 2020 : p. 3854982.

31. Carnicelli, A.P., et al., Elevated Uric Acid Prevalence and Clinical Outcomes in Patients with Heart Failure with Preserved Ejection Fraction: Insights from RELAX. Am J Med, 2020.

32. Derosa, G., P. Maffioli, and A. Sahebkar, Improvement of plasma adiponectin, leptin and C-reactive protein concentrations by orlistat: a systematic review and meta-analysis. Br J Clin Pharmacol, 2016.81 (5): p. 819-34.

Table 1.Characteristices of the included studies

\begin{tabular}{|c|c|c|c|c|c|c|c|c|}
\hline $\begin{array}{l}\text { Author } \\
\text { (year) }\end{array}$ & $\begin{array}{l}\text { Study } \\
\text { design }\end{array}$ & $\begin{array}{l}\text { Study } \\
\text { group }\end{array}$ & $\begin{array}{l}\text { Duration } \\
\text { (month) }\end{array}$ & $\begin{array}{l}\text { Gender } \\
\mathrm{M} / \mathrm{F}\end{array}$ & $\begin{array}{l}\text { Sample size } \\
\text { Orlistat/ } \\
\text { Control }\end{array}$ & Age (year) & $\begin{array}{l}\text { Other in- } \\
\text { tervention } \\
\text { (Study } \\
\text { group) }\end{array}$ & $\begin{array}{l}\text { Notes } \\
\text { about } \\
\text { subject }\end{array}$ \\
\hline $\begin{array}{l}\text { B. } \\
\text { Guy-Grand } \\
(2004\end{array}$ & $\begin{array}{l}\text { randomized, } \\
\text { double- } \\
\text { blind } \\
\text { placebo- } \\
\text { controlled } \\
\text { parallel- } \\
\text { group } \\
\text { clinical } \\
\text { trial }\end{array}$ & $\begin{array}{l}120 \mathrm{mg}(\mathrm{tid}) \\
\text { placebo }\end{array}$ & 6 & $\mathrm{M} / \mathrm{F}$ & $458 / 458$ & $18-65$ & $\begin{array}{l}\text { mildly } \\
\text { reduced- } \\
\text { calorie } \\
\text { diet }\end{array}$ & $\begin{array}{l}\text { obese } \\
\text { patient } \\
(\mathrm{BMI} \\
28-40 \\
\mathrm{~kg} / \mathrm{m} 2) \\
\text { untreat } \\
\text { type } 2 \\
\text { diabete } \\
\text { untreat } \\
\text { hyperte } \\
\text { sion } \\
\text { hyperch }\end{array}$ \\
\hline
\end{tabular}




\begin{tabular}{|c|c|c|c|c|c|c|c|c|}
\hline $\begin{array}{l}\text { Author } \\
\text { (year) }\end{array}$ & $\begin{array}{l}\text { Study } \\
\text { design }\end{array}$ & $\begin{array}{l}\text { Study } \\
\text { group }\end{array}$ & $\begin{array}{l}\text { Duration } \\
\text { (month) }\end{array}$ & $\begin{array}{l}\text { Gender } \\
\mathrm{M} / \mathrm{F}\end{array}$ & $\begin{array}{l}\text { Sample size } \\
\text { Orlistat/ } \\
\text { Control }\end{array}$ & Age (year) & $\begin{array}{l}\text { Other in- } \\
\text { tervention } \\
\text { (Study } \\
\text { group) }\end{array}$ & $\begin{array}{l}\text { Notes } \\
\text { about } \\
\text { subject }\end{array}$ \\
\hline $\begin{array}{l}\text { T. P. } \\
\text { Didangelos } \\
(2004)\end{array}$ & $\begin{array}{l}\text { randomized } \\
\text { open-label } \\
\text { prospective } \\
\text { multicenter } \\
\text { parallel- } \\
\text { group } \\
\text { controlled } \\
\text { clinical } \\
\text { trial }\end{array}$ & $\begin{array}{l}360 \\
\text { mg/day } \\
\text { control }\end{array}$ & 6 & $\mathrm{M} / \mathrm{F}$ & $94 / 32$ & $30-72$ & $\begin{array}{l}\text { hypocaloric } \\
\text { diet (HCD) } \\
\text { (500 } \\
\text { calories } \\
\text { below the } \\
\text { needs (mean } \\
\text { daily } \\
\text { calorie } \\
\text { intake } \\
1300)\end{array}$ & $\begin{array}{l}\text { type } 2 \\
\text { treated } \\
\text { with or } \\
\text { antidial } \\
\text { agents } \\
\text { (metfor } \\
\text { alone o } \\
\text { combin } \\
\text { tion wit } \\
\text { sulfony } \\
\text { lureas) } \\
\text { patient } \\
\text { had the } \\
\text { MetSyn }\end{array}$ \\
\hline $\begin{array}{l}\text { Giuseppe } \\
\text { Cocco } \\
(2005)\end{array}$ & $\begin{array}{l}\text { randomized } \\
\text { double } \\
\text { blind } \\
\text { placebo- } \\
\text { controlled } \\
\text { parallel- } \\
\text { group } \\
\text { clinical } \\
\text { trial }\end{array}$ & $\begin{array}{l}120 \mathrm{mg}(\mathrm{tid}) \\
\text { placebo }\end{array}$ & 6 & $\mathrm{M} / \mathrm{F}$ & $45 / 45$ & at least 35 & $\begin{array}{l}\text { standardized } \\
\text { physical } \\
\text { pro- } \\
\text { gram(walk } \\
\text { briskly for } \\
\text { at least } 30 \\
\text { min per } \\
\text { day) +fat- } \\
\text { restricted } \\
\text { diet }\end{array}$ & $\begin{array}{l}\text { adipose } \\
\text { patient } \\
\text { (BMI } 3 \\
\text { 40kg/m } \\
\text { metabo } \\
\text { syn- } \\
\text { drome, } \\
\text { type } 2 \\
\text { pertens } \\
\text { treated } \\
\text { with dr } \\
\text { coronar } \\
\text { heart } \\
\text { disease } \\
\text { comitar } \\
\text { cardiac } \\
\text { dysfunc } \\
\text { Antidia } \\
\text { betic } \\
\text { drugs }\end{array}$ \\
\hline $\begin{array}{l}\text { T. D. } \\
\text { Filippatos } \\
(2005)\end{array}$ & $\begin{array}{l}\text { randomized } \\
\text { open-label } \\
\text { parallel- } \\
\text { group } \\
\text { clinical } \\
\text { trial }\end{array}$ & $\begin{array}{l}120 \mathrm{mg}(\mathrm{tid}) \\
\text { control }\end{array}$ & 3 & $\mathrm{M} / \mathrm{F}$ & $28 / 29$ & $53 \pm 11$ & $\begin{array}{l}\text { micronised } \\
\text { fenofibrate } \\
200 \\
\text { mg/day + } \\
\text { low-calorie } \\
\text { low-fat diet } \\
\text { (500-1000 } \\
\text { kcal } \\
\text { reduction } \\
\text { in daily } \\
\text { energy) }\end{array}$ & $\begin{array}{l}\text { Overwe } \\
\text { and obe } \\
(\mathrm{BMI}> \\
\mathrm{kg} / \mathrm{m} 2) \\
\text {,MetS }\end{array}$ \\
\hline
\end{tabular}




\begin{tabular}{|c|c|c|c|c|c|c|c|}
\hline $\begin{array}{l}\text { Author } \\
\text { (year) }\end{array}$ & $\begin{array}{l}\text { Study } \\
\text { design }\end{array}$ & $\begin{array}{l}\text { Study } \\
\text { group }\end{array}$ & $\begin{array}{l}\text { Duration } \\
\text { (month) }\end{array}$ & $\begin{array}{l}\text { Gender } \\
\mathrm{M} / \mathrm{F}\end{array}$ & $\begin{array}{l}\text { Sample size } \\
\text { Orlistat/ } \\
\text { Control }\end{array}$ & Age (year) & $\begin{array}{l}\text { Other in- } \\
\text { tervention } \\
\text { (Study } \\
\text { group) }\end{array}$ \\
\hline $\begin{array}{l}\text { E. S. } \\
\text { Nakou } \\
(2008)\end{array}$ & $\begin{array}{l}\text { randomized } \\
\text { open-label } \\
\text { parallel- } \\
\text { group } \\
\text { clinical } \\
\text { trial }\end{array}$ & $\begin{array}{l}120 \mathrm{mg}(\mathrm{tid}) \\
\text { control }\end{array}$ & 6 & $\mathrm{M} / \mathrm{F}$ & $29 / 28$ & $55 \pm 10$ & $\begin{array}{l}\text { BMI>2 } \\
\mathrm{kg} / \mathrm{m} 2 \\
\text { perchol } \\
\text { terolem } \\
\text { antihyp } \\
\text { tensive } \\
\text { drugs o } \\
\text { stabilise } \\
\text { dose for } \\
\text { least } 8 \\
\text { weeks } \\
\text { before } \\
\text { entry tc } \\
\text { the stuc }\end{array}$ \\
\hline \multirow[t]{2}{*}{$\begin{array}{l}\text { Jinghua } \\
\text { Song } \\
(2018)\end{array}$} & \multirow[t]{2}{*}{$\begin{array}{l}\text { randomized } \\
\text { open-label } \\
\text { parallel- } \\
\text { group } \\
\text { clinical } \\
\text { trial }\end{array}$} & $\begin{array}{l}120 \mathrm{mg}(\mathrm{tid}) \\
\text { control }\end{array}$ & \multirow[t]{2}{*}{3} & $\mathrm{~F}$ & $60 / 60$ & \multirow[t]{2}{*}{$18-40$} & \multirow{2}{*}{$\begin{array}{l}\text { Diane- } \mathrm{PCOS} \\
35+\text { individualiBedII }>\text { : } \\
\text { low-fat diet } \mathrm{kg} / \mathrm{m} 2 \\
\text { and } \\
\text { moderate } \\
\text { daily } \\
\text { physical } \\
\text { activity } \\
\text { metformin(500mg/day } \\
\text { for the first } \\
\text { week/500mg } \\
\text { twice daily } \\
\text { for the next } \\
\text { week) } \\
\text { +Diane-35 } \\
\text { (OMD } \\
\text { group) }+ \\
\text { individual- } \\
\text { ized low-fat } \\
\text { diet and } \\
\text { moderate } \\
\text { daily } \\
\text { physical } \\
\text { activity }\end{array}$} \\
\hline & & $\begin{array}{l}120 \mathrm{mg}(\mathrm{tid}) \\
\text { control }\end{array}$ & & $\mathrm{F}$ & $60 / 60$ & & \\
\hline
\end{tabular}




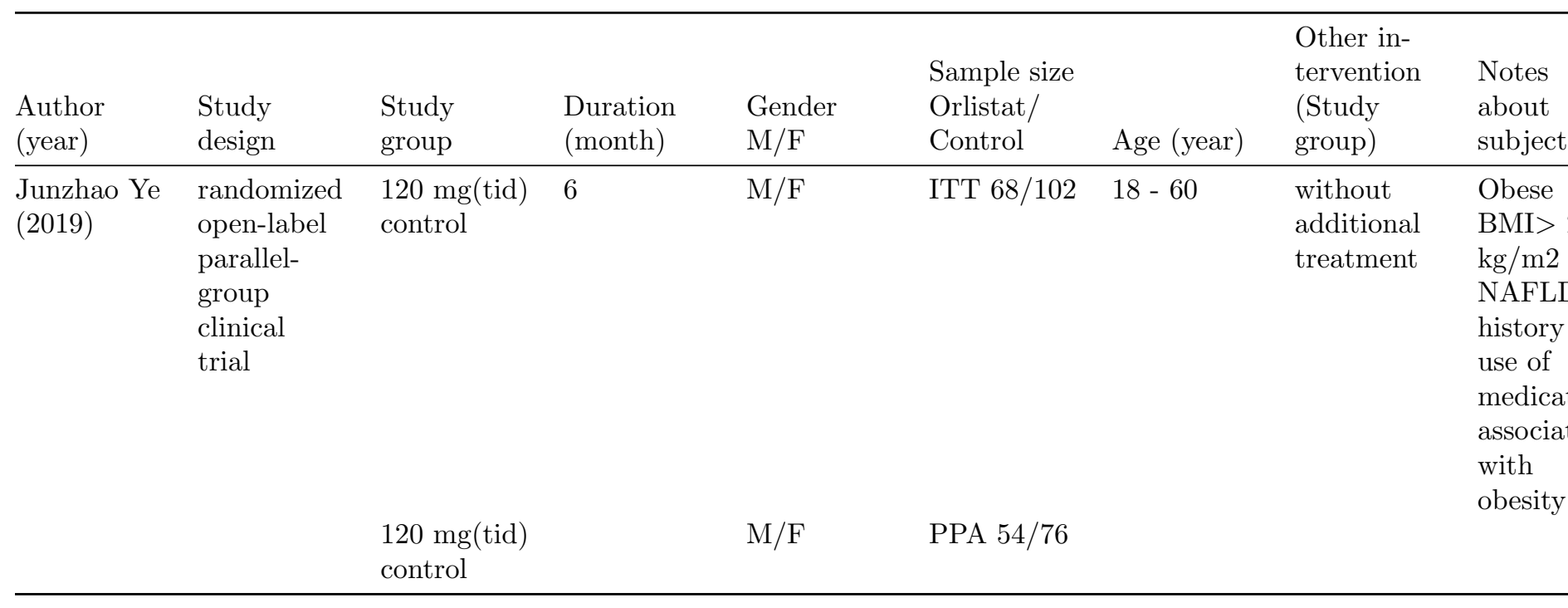

Table 2. Subgroup analysis of included randomized controlled trials in meta-analysis of the effect of orlistat on serum uric acid

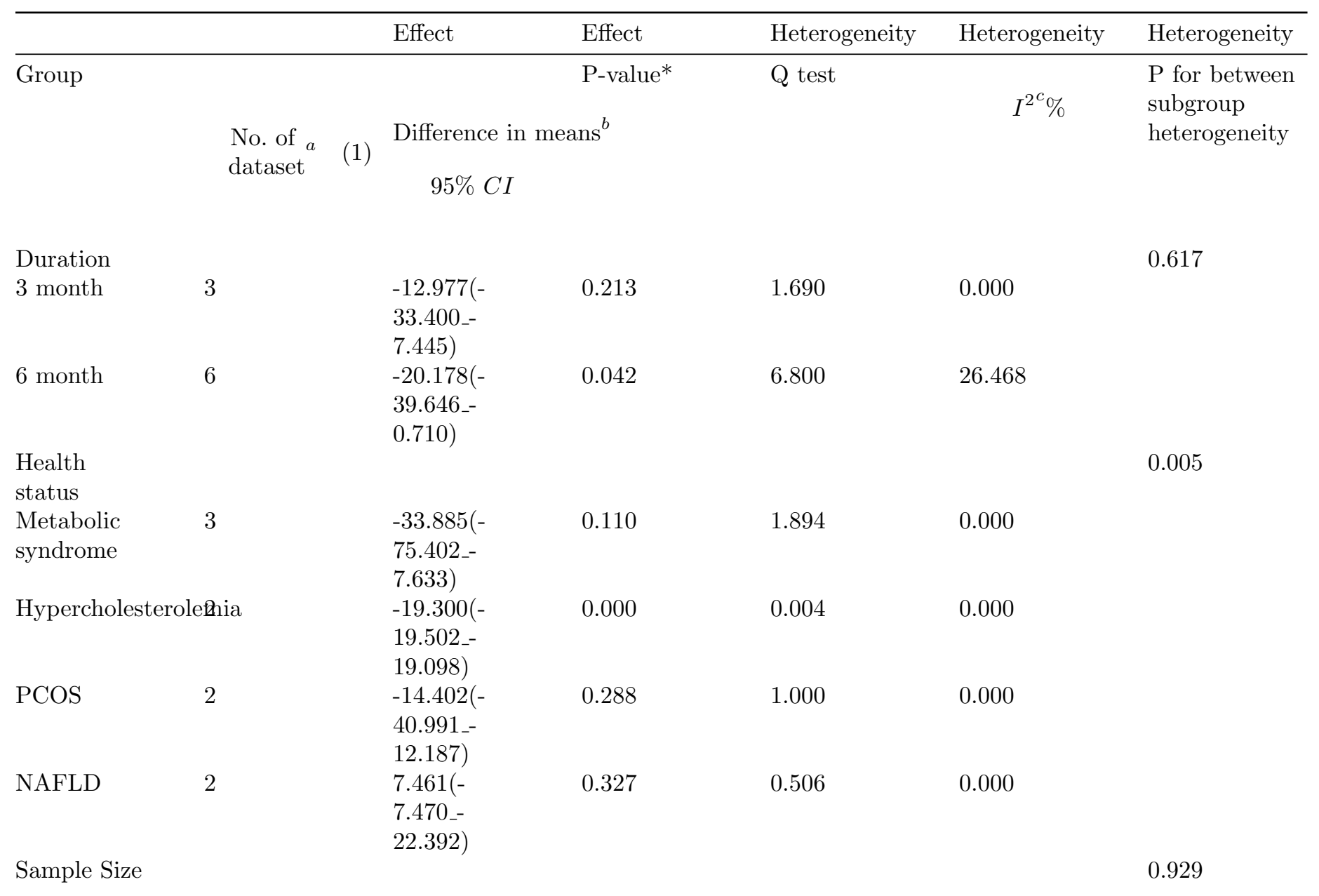




\begin{tabular}{|c|c|c|c|c|c|c|}
\hline & & Effect & Effect & Heterogeneity & Heterogeneity & Heterogeneity \\
\hline$<100$ & 3 & $\begin{array}{l}-17.105(- \\
36.745_{-} \\
2.535)\end{array}$ & 0.088 & 0.544 & 0.000 & \\
\hline$>100$ & 6 & $\begin{array}{l}-18.310(- \\
36.045_{-} \\
0.575)\end{array}$ & 0.043 & 8.349 & 40.110 & \\
\hline Plus orlistat & & & & & & 0.017 \\
\hline $\begin{array}{l}\text { Low } \\
\text { calorie/low } \\
\text { fat diet }\end{array}$ & 3 & $\begin{array}{l}-35.949(- \\
66.772_{-} \\
5.127)\end{array}$ & 0.022 & 2.200 & 9.109 & \\
\hline $\begin{array}{l}\text { Low } \\
\text { calorie/low } \\
\text { fat diet }+ \\
\text { Medication }\end{array}$ & 4 & $\begin{array}{l}-15.319(- \\
30.232_{-}- \\
0.406)\end{array}$ & 0.044 & 2.826 & 0.000 & \\
\hline Nothing & 2 & $\begin{array}{l}7.461(- \\
7.470_{-} \\
22.392)\end{array}$ & 0.327 & 0.506 & 0.000 & \\
\hline
\end{tabular}

a. number of studies included in analysis.

b. The pooled effect was calculated using Comprehensive Meta-analysis software v2.

c . The $I^{2}$ statistic was calculated by using Cochran's test, and $I^{2}>50 \%$ was considered to indicate significant heterogeneity across studies

$*$ p-value $<0.05$ (two-tailed) were considered significant

\section{Hosted file}

Figure1.docx available at https://authorea.com/users/359855/articles/481623-effect-oforlistat-on-serum-uric-acid-level-in-adults-a-systematic-review-and-meta-analysis-ofrandomized-controlled-trials

\section{Hosted file}

Figure2.docx available at https://authorea.com/users/359855/articles/481623-effect-oforlistat-on-serum-uric-acid-level-in-adults-a-systematic-review-and-meta-analysis-ofrandomized-controlled-trials

\section{Hosted file}

Figure3.docx available at https://authorea.com/users/359855/articles/481623-effect-oforlistat-on-serum-uric-acid-level-in-adults-a-systematic-review-and-meta-analysis-ofrandomized-controlled-trials

\section{Hosted file}

Figure4.docx available at https://authorea.com/users/359855/articles/481623-effect-oforlistat-on-serum-uric-acid-level-in-adults-a-systematic-review-and-meta-analysis-ofrandomized-controlled-trials

\section{Hosted file}

Figure5.docx available at https://authorea.com/users/359855/articles/481623-effect-oforlistat-on-serum-uric-acid-level-in-adults-a-systematic-review-and-meta-analysis-ofrandomized-controlled-trials 


\section{Hosted file}

Figure6.docx available at https://authorea.com/users/359855/articles/481623-effect-oforlistat-on-serum-uric-acid-level-in-adults-a-systematic-review-and-meta-analysis-ofrandomized-controlled-trials 